\title{
Proof during the prejudicial inquiry of smugglingof narcotic drugs, psychotropic substances, their analogs, or precursors under the legislation of Ukraine
}

\section{Доказування під час досудового розслідування контрабанди наркотичних засобів, психотропних речовин, їх аналогів чи прекурсорів за законодавствомУкраїни}

Received: April 3, 2021

\begin{abstract}
The object of the study is social relations regarding the prejudicial inquiry of smuggling narcotic drugs, psychotropic substances, their analogs or precursors. It has been found that there are scholars who choose different definitions for interpreting the nature of the proof, but are unanimous about the role of this process in proving a person's guilt and choosing an adequate punishment.

The authors use a set of scientific methods of modern epistemology as well as comparative, special legal, logical and other methods.

We propose to analyze all the circumstances that are subject to proof during the prejudicial inquiry of smuggling of narcotic drugs, psychotropic substances, their analogs, or precursors. In this paper must identify the general grounds that must be proved in each crime and the specific circumstances that are important to prove only in the case of smuggling narcotic drugs, psychotropic substances, their analogs, or
\end{abstract}

Accepted: May 3, 2021

Written by:

Oleg Reznik ${ }^{53}$

https://orcid.org/0000-0003-4569-8863

Web of Science researcher code: AAJ-3122-2020

Maksym Pochtovyi ${ }^{54}$

https://orcid.org/0000-0002-3135-4974

Web of Science researcher code:I-5532-2017

Kateryna Yanishevska ${ }^{55}$

https://orcid.org/0000-0002-3648-5543

Web of Science researcher code: ABD-3281-2020

Andrii Butyrskyi ${ }^{56}$

https://orcid.org/0000-0002-3225-7017

Web of Science researcher code: T-6709-2018

\footnotetext{
${ }^{53}$ Doctor of Juridical Sciences, Associate Professor, Department of Administrative, Economic Law and Financial and Economic Security, Sumy State University, Ukraine.

${ }^{54}$ Candidate of Juridical Sciences, Associate Professor, Kryvyi Rig Faculty of Dnipropetrovsk State University of Internal Affairs, Ukraine.

${ }^{55}$ Candidate of Juridical Sciences, Associate Professor, Senior Lecturer of the Department of Criminal Law Disciplines and Legal Proceedings, Sumy State University, Ukraine.

${ }^{56}$ Doctor of Law, Professor of Department of Private Law, Yuriy Fedkovych Chernivtsi National University, Ukraine
} 
precursors.

The conclusion is made about the importance of prosecution of persons who have committed a crime under Article 305 of the Criminal Code of Ukraine. Therefore, we propose to include in the subject of evidence for the prejudicial inquiry.

Key Words: narcotic drugs,prejudicial inquiry, proper procedural support of criminal psychotropic substances, proof, smuggling.

випадку вчинення контрабанди наркотичних засобів, психотропних речовин, їх аналогів чи прекурсорів. Робиться висновок про значущість належного процесуального супроводу кримінального переслідування, осіб, які вчинили злочин, передбачений статтею 305 Кримінального кодексу України. Тому, авторами запропоновано до предмета доказування щодо розслідування контрабанди наркотичних засобів, психотропних речовин, їх аналогів чи прекурсорів включати й обставини, які визначені в диспозиції статті 305 Кримінального кодексу України та обставини, які не входять до предмета доказування, але мають важливе значення для судового розгляду справи по суті, наприклад, про особу обвинуваченого та обставини стосовно причин та умов вчинення злочину

Ключовіслова: доказування, досудове розслідування, контрабанда, наркотики, психотропні речовини.

\section{Introduction}

The current socio-economic and political situation has led to a significant increase in economic crime in Ukraine (Podorozhnii, Obushenko, Harbuziuk, \& Platkovska, 2020). One of the most common of which is the smuggling of narcotic drugs, psychotropic substances, their analogs, or precursors. Smuggling of illegal goods (Groot, 2013) - is an activity to which they are adjusted to and which creates conditions for acquisition income from illegal transportation across state borders in violation of the current rules. The smuggling of these goods not only distorts the state's economy (Buehnand, \& Farzanegan, 2012) but also creates a significant threat to the health of the population, as it undermines its capacity (MacKenzie, Mitchell, \& Wilson, 2011).

That is why ensuring counteraction to this phenomenon is important and urgent for our state. However, given the trans-border nature of this crime, controlling the level of smuggling is not only the responsibility of a particular country but also part of synergetic governance around the world (Sui, Feng, \& Chang, 2018). After all, only the development of unified, streamlined requirements will counteract this deconstructive phenomenon in all its aspects and create conditions for mutual assistance from other states. Criminal liability for smuggling of drugs, psychotropic substances, their analogs or precursors under Ukrainian legislation conforms to international treaties of our state, which provide state duty to prosecute perpetrators of illicit trafficking, which pose an increased danger to the public health. These include the Single Convention on Narcotic Drugs (1961), the Convention on Psychotropic Substances (1971), and the United Nations Convention against Illicit Traffic in Narcotic Drugs and Psychotropic Substances (1988) (Pilnik, 2016). Ukraine's orientation towards integration into the European Union implies the obligation of the international community to ensure compliance of the national legal system with the standards of the European community. It also includes the creation of effective mechanisms to counter the smuggling of narcotic drugs, psychotropic substances, their analogs, or precursors (Nastyuk, Mikhailov, Izbash, \& Kondratenko, 2020). One of the stages of domestic legislation adoption to international and European standards was the updating of criminal procedure legislation of Ukraine in 2012: the procedural form of prejudicial inquiry was changed, court functions were expanded to control human rights and freedoms. Besides, approaches to the evidentiary process in criminal proceedings have changed significantly (Ponomarenko, Havryliuk, Anheleniuk, \& Drozd, 2020).

At the same time, international cooperation should serve only as a guide, and the developed specific legal measures and tools for their implementation should be adapted to the specifics of political, economic, and sociocultural development of each individual (Bondarenko, Reznik, Yevgen, Andriichenko, \& 
Stohova, 2020).

Currently, the core of the criminal process is cognitive, evidentiary activity, which involves establishing as prescribed by law by the subjects conducting the prejudicial inquiry and judicial proceeding of the circumstances of the criminal offense and substantiate the conclusions (Ishchenko, 2011), because the prosecution is a very complex process that must meet several standards and regulations. The prejudicial inquiry, therefore, is a key player in this activity. Currently, the prejudicial inquiry is one of the main forms of pre-trial preparation of materials, the purpose of which is to prepare criminal proceedings for trial, as well as for the final decision to terminate the criminal proceedings (Gatiyatullina, \& Samitov, 2019). The prejudicial inquiry of smuggling of narcotic drugs, psychotropic substances, their analogs, or precursors under the legislation of Ukraine has certain features due to the specifics of this crime, especially in the context of the evidentiary process.

That is why the authors consider it necessary to examine in depth not only the process of prejudicial inquiry, but also the process of proving during the prejudicial inquiry of the smuggling of narcotic drugs, psychotropic substances, their analogs, or precursors under Ukrainian legislation.

\section{Theoretical framework}

The theoretical basis of the study is scientific papers devoted to the proof during the prejudicial inquiry of smuggling of narcotic drugs, psychotropic substances, their analogs, or precursors under the legislation of Ukraine.

Thus, Soroka S., Rimarchuk R., understand by the term "proof" the collection, verification, and evaluation of evidence to establish the circumstances relevant to criminal proceedings. Proof exists as much as the man himself does. Procedural evidence and law enforcement are associated with the emergence of law and statehood. The current situation in the field of proof is due to the long-term process of law and the state development (scientific disputes, discussions, views, judgments of generations of scientists) (Soroka \& Rimarchuk, 2017).

Rybalka O; defines proof as to the process of evidence reception and using to reproduce the real picture of the event under investigation. It is the only means of achieving the goals of justice, protection of the rights, and legitimate interests of persons involved in criminal proceedings, so the question of proof and evidence, according to most researchers, were and remain the core of the criminal procedure (Rybalka, 2011)

Shcheritsa S. outlined that proof is a single and inseparable process, the elements of which are closely intertwined with each other. It is carried out at different stages with the inherent procedural features of each of them. By nature, criminal procedural evidence is a cognitive activity, the result of which is the formation of a subjective image of objective reality about the event of the past. And by character, it is a complex structured activity and should be considered, on the one hand, as establishing and investigating the circumstances of the case, included in the subject of proof, i.e. the activities of relevant state authorities and participants in the process of collecting (forming), verifying and evaluating evidence, on the other - as a logical formulation and justification of a thesis (Shcheritsa, 2015).

Komissarchuk $\mathrm{Yu}$. is convinced that proof is a process that takes place in time and space, not a one-time act. This is the only continuous process of transition from ignorance to knowledge, from incomplete knowledge to more complete. Proof permeates all stages of the criminal procedure, from the opening of criminal proceedings to its review in higher courts. Besides, the scientist draws attention to the fact that proof is not only a practical but also a mental and logical activity of persons conducting criminal proceedings and other participants. It, like knowledge in any other field of science or practice, combines empirical and rational principles (Komissarchuk, 2011).

Instead, Kostin M. argues that the collection and practice of examining evidence should not be included in the notion of proof in criminal proceedings. They precede the proof, and their results serve as the basis for the proof, important for its comprehensiveness, reliability, and effectiveness. Therefore, in his opinion, the proof is the activity of the prosecutor, investigator, other subjects authorized by the criminal procedure law, the basis of which is logical and analytical operations to verify and evaluate the evidence to establish grounds for criminal liability and punishment, protection of innocent persons from unfounded conviction by using evidence to substantiate and motivate the relevant procedural decisions (Kostin, 2004). 


\section{Methodology}

In accordance with the goal, the article uses a set of scientific methods of modern epistemology. The methodological basis of the study is the theory of knowledge of legal phenomena, as well as conceptual provisions developed by experts in the field of criminal procedure law. The study also used special research methods, in particular: comparative - to compare the rules of criminal substantive and procedural law; special legal used for in-depth study of regulations on evidence during the pre-trial investigation of smuggling of narcotic drugs, psychotropic substances, their analogues or precursors. In order to form logical, systematic and consistent conclusions, logical-legal and systematic methods were used. The above and other methods of scientific research were used in the article in conjunction, which in turn ensured the comprehensiveness of the research, the objectivity of the obtained scientific results.

\section{Results and discussion}

The investigation of each crime involves proving a certain list of legally defined circumstances:

- event of the criminal offense (time, place, method, and other circumstances of the criminal offense);

- the guilt of the accused in the commission of a criminal offense, the form of guilt, motive, and purpose of the criminal offense;

- the type and amount of damage caused by a criminal offense, as well as the number of procedural costs;

- circumstances that affect the severity of the criminal offense, characterize the identity of the accused, aggravate or mitigate the punishment, which excludes criminal liability or are grounds for closing criminal proceedings;

- circumstances that are the basis for release from criminal liability or punishment;

- circumstances confirming that money, valuables and other property subject to special confiscation received as a result of a criminal offense and/or are income from such property, or were intended (used) to persuade a person to commit a criminal offense, financing and/or material securing a criminal offense or remuneration for its commission, or is the subject of a criminal offense, including related to their illicit trafficking, or found, manufactured, adapted or used as a means or instrument of committing a criminal offense;
- circumstances that are the basis for the application of measures of criminal law to legal entities (Law № 4651-VI, 2012).

At the same time, the investigation of a certain crime, although it must meet several standardized conditions, is still characterized by certain methodological and tactical features, which in turn necessitates the study of other evidentiary facts that are not part of the general evidence but are important to establish the fact of a person's guilt and bringing him to criminal responsibility. Besides, most of the circumstances may be used by the judge in choosing the punishment that will be necessary and sufficient to correct the guilty person. Therefore, in the author's opinion, during the investigation of smuggling of narcotic drugs, psychotropic substances, their analogs, or precursors, the circumstances to be proved also include circumstances established by the disposition of Article 305 of the Criminal Code of Ukraine and circumstances that are not subject to proof but have important for the trial on the merits (Soroka, 2015). That is why the authors propose to focus on the peculiarities of proof in the prejudicial inquiry of smuggling of narcotic drugs, psychotropic substances, their analogs, or precursors under the legislation of Ukraine.

Proof of the event of a criminal offense (time, place, method)

First of all, it is important to note that the concepts of "event of a criminal offense" and "grounds of criminal responsibility" cannot be equated. The Criminal Code of Ukraine clearly states that the ground of criminal responsibility is the presence in the actions of a person of essential elements of an offense. While the Criminal Procedure Code states that the ground for initiating criminal proceedings is the occurrence of a criminal offense. The event of a criminal offense should be associated with the opening of criminal proceedings, and the subject of evidence should be expanded at the expense of criminal responsibility (Krasiy, 2015).

Fixing the time of the commission of a criminal offense under Article 305 of the Criminal Code of Ukraine, of course, depends on the circumstances of the criminal proceedings. Particular accuracy in determining the time is required in the case when drugs are moved outside the customs check-point. Because in such cases time may indicate whether there was an illegal (outside the established time of customs clearance and work of the customs authority) crossing the border with drugs, psychotropic 


\section{AMAZONDA}

substances, their analogs, or precursors (Malyuga, 2014)

It should be noted that in most cases the place of commission of a criminal offense under Article 305 of the Criminal Code of Ukraine depends on the method of illegal movement of goods, objects, substances across the customs border (movement outside customs control, using hiding places, falsification of customs and other documents, etc.). In one place criminals move smuggling by bypassing, bypassing customs, customs posts, in another - outside the established time for customs control (Shevchuk, 2003)

Typical methods of smuggling drugs, psychotropic substances, their analogs or precursors are:

1. Movement of drugs across the customs border of Ukraine outside customs control. Criminals use residents of the border area who are well aware of secret border crossings using the local landscape. For a fee, the so-called conductors escort the smugglers outside the customs checkpoint. They also use the assistance of certain corrupt servicemen of the State Border Guard Service of Ukraine, who do not issue a reorganization permit to cross the border in an unspecified place.

2. Concealment of narcotic drugs, psychotropic substances, their analogs, or precursors from customs control with the use of various hiding places in vehicles, transported and sent goods, luggage and body, and human cavity, which make it impossible to detect them (Nikiforchuk D., 2006).

3. The next method is the use of falsified (forged or invalid) documents for the transportation across the border of narcotic drugs, psychotropic substances, their analogs, or precursors for their identification. In the Poltava region, the Security Service of Ukraine together with the prosecutor's office blocked an international channel for drug smuggling from Europe. Thus, a 50-year-old organizer of drug trafficking was detained in Kremenchuk. Drugs in this case were transported across the border, according to forged documents, as medicines for cancer patients (Express analysis of the state of crime, 2015).

4. Non-declaration or inaccurate declaration of data on goods transported across the customs border of Ukraine. Thus, proving the event of a criminal offense has not only procedural but also substantive significance.

\section{Proof of the guilt of accused in committing a criminal offense}

Paragraph 2 of Part 1 of Article 91 of the Criminal Procedure Code of Ukraine states that it is necessary to establish the guilt of accused in committing a criminal offense (Law № 4651-VI, 2012).Guilt is a category of criminal procedural law, which means proving by evidence that a specific person committed a crime. According to Article 23 of the Criminal Code of Ukraine, an act can be considered a crime only if there is guilt, and a person can be found guilty of committing a crime if he has a certain mental attitude to the act and its consequences (in the form of intent and negligence) (Law № 2341-III, 2001).

Emphasizing the forensic significance of the guilt of a person as an element of the subject of evidence, the authors note that its establishment is a process of identifying a particular person and clarifying his involvement in the event of a criminal offense and its connection. Along with the proof of the person's guilt, the motive and purpose of the crime must also be proved, which, although optional for the qualification of the crime, must be taken into account when determining the public danger of the perpetrator, the person of the offender and sentencing. Thus, to individualize criminal responsibility, in our opinion, the personal qualities of the suspect (accused) are subject to proof, namely his behavior before and after the commission of a criminal offense, the presence of other circumstances that comprehensively and fully characterize the identity of the offender. To properly characterize the identity of the offender should establish the motive and purpose of the criminal offense he committed. The motives for committing the crime are the pathogens (needs, interests, aspirations, etc.) that caused the suspect, the accused to decide to commit the act, provided that he is aware of its illegality. Motive and purpose are organically interconnected, as they are reflected in the subjective sphere of man. Sometimes it is impossible to properly understand and comprehend the motive of a crime without defining the purpose, just as it is impossible to realize the purpose of the crime without a motive. Absence in the indictment, and then in the conviction of the reference to the motive and the purpose of the commission of a crime complicates legal qualification of act and 
distinction of similar structures of offenses (Goncharenko, Nora, \& Shumila, 2012).

Proof of the type and amount of damage caused by a criminal offense

Videnko Y. argues that the type of damage and its amount, expressed in property (monetary) equivalent, is the subject of a civil lawsuit. Besides, proving the type and amount of damage caused in criminal proceedings involves not only the substantiation of a civil lawsuit for damages but is primarily of criminal law significance (Videnko, 2014). First, providing crime investigators with compensation for damage caused by a criminal offense requires identifying the various circumstances to be proved, determining the type and amount of damage caused by the criminal offense, as well as the victim, etc., as this determines whether the perpetrator is identified, or will prove her guilt. Secondly, the proof of the type and amount of damage caused by a criminal offense is of paramount importance to provide compensation to the victim. Third, the type and amount of damage caused by a criminal offense must be proved in all criminal proceedings. Fourth, the separation of the type and amount of damage caused by a criminal offense is appropriate, as it is important not only for the qualification of the crime but also for compensation for the damage that occurs after the criminal-legal qualification. In turn, the investigator must be aware of its importance and not focus only on proving the event of a criminal offense and the guilt of the person who committed it (Sofin, 2016).

Proof of circumstances that affect the criminal of the criminal act, aggravate or mitigate penalties that exclude criminal responsibility or are grounds for closing criminal proceedings

The legal significance of mitigating circumstances (as well as aggravating circumstances) is multifaceted. Such mitigating circumstances are directly provided for in the criminal law, such as the commission of a criminal offense under the influence of threat, coercion, and the commission of a crime over the limits of self-defense, the performance of a special task to prevent or detect a criminal group or criminal organization. cases provided for by the Criminal Code of Ukraine, as well as others not specified in Article 66 of the Criminal Code of Ukraine, may simultaneously have the significance of signs of a lesser criminal offense or signs of committing an illegal act, including criminal, victims, another person, etc. Thus, timely identification of them only as mitigating punishments in the course of further proceedings in the case can lead, and often leads to the mitigation of the accusation itself, and even to rehabilitation. And mitigating circumstances such as sincere repentance, voluntary compensation for damages, or redress in subsequent proceedings often become one of the grounds for exemption from criminal responsibility in connection with effective repentance, in connection with reconciliation of the perpetrator with the victim. Mitigating circumstances, including those that characterize the person guilty, are taken into account when releasing the sentence and serving it (Popelyushko, 2007).

Proof of circumstances that are grounds for release from criminal responsibility or punishment

Thus, when applying for revocation on absolute discharge, the authorized person, depending on the grounds specified in the relevant provisions of the Criminal Code of Ukraine, must establish the gravity of the criminal offense, the fact of its first or negligence, and prove sincere remorse, active assistance in the investigation of a criminal offense, the fact of compensation, changes in the situation of the offense. Only a full investigation of these circumstances guarantees the issuance of a lawful and reasonable decision that will fully ensure the rights, freedoms, and legitimate interests of the participants in the criminal proceedings (Torbas, 2015).

Proof of circumstances confirming that money, valuables and other property subject to special confiscation received as a result of a criminal offense and/or are income from such property, or were intended (used) to persuade a person to commit a criminal offense, financing and / or material support of a criminal offense or reward for its commission

This circumstance occupies a fundamental place for the investigation, as at this stage the establishment of material evidence of criminal activity, their location, as well as property subject to confiscation and asset forfeiture. The authors believe that this is an extremely progressive provision that will help to materially and financially punish the offender and expand the powers of law enforcement agencies in the fight against money laundering (Tsimbalyuk, 2014).

For the domestic theory of criminal law, such a measure as asset forfeiture has long been known and studied in many ways. However, for a long time asset forfeiture was the subject of 
discussions of scholars, in particular, regarding its legal nature and, first of all, due to the lack of proper enshrinement of its criminal status in substantive law (Pirozhenko, 2015) In our opinion, the simultaneous existence of confiscation of property and asset forfeiture pursues the goal of the widest possible "coverage" of financial resources of offenders. In this case, the confiscation of property relates to the values for which the right of ownership arose, special confiscation relates to things and values for which the offender could not have the right of ownership, because it would be contrary to civil law.

This apparition is directly related to the provisions of the Civil Code of Ukraine (Law № 435-IV, 2004): according to Part 1 of Article 328, the right of ownership is acquired on grounds not prohibited by law; according to paragraph 10 of part 1 of Article 346 confiscation is the basis for termination of ownership; according to part 1 of article 354 the confiscated property becomes the property of the state free of charge as a sanction for commission of an offense in the cases established by the law (Orlovskaya, 2016)

Proof regarding the subject of the criminal offense

As you know, the subject of a criminal offense, as a rule, is an optional feature of the criminal offense. At the same time, the analysis of the disposition of Article 305 of the Criminal Code of Ukraine shows that the subject of this criminal offense acquires significant features, and therefore affects the qualification of the act and the measures of punishment.

The subject of the analyzed criminal offense is narcotic drugs, psychotropic substances, their analogs, and precursors. Drugs are included in the approved list of substances of natural and synthetic nature, drugs and plants that pose a danger in case of abuse. Psychotropic substances, in turn, are drugs included in the approved list of substances of natural and synthetic origin, natural materials that can cause addiction, or cause depression, or stimulate the central nervous system, or cause disturbances in the perception of emotions, thinking, or behavior and pose a danger in case of abuse. Drug precursors are substances and their salts used in the manufacture and manufacture of drugs (acetone, ethyl ether, hydrochloric acid, sulfuric acid, etc.). Analogs of narcotic drugs and psychotropic substances are synthetic or natural substances prohibited for circulation on the territory of Ukraine, not included in the List of narcotic drugs, psychotropic substances, and precursors, the chemical structure and properties of which are similar to the chemical structure and properties of narcotic drugs and psychotropic substances, which they reproduce (Law № 60/95-VR, 1995).

To prove the smuggling of narcotic drugs, psychotropic substances, their analogs or precursors under the legislation of Ukraine, it is very important to conduct an examination using special knowledge and establish the conformity of seized substances, therefore the legally approved list of narcotic drugs, psychotropic substances, their analogs, and precursors. Because the absence of the subject of this criminal offense is the basis for closing the criminal proceedings under this article.

\section{Proof of weapons and means, smuggling of narcotic drugs, psychotropic substances, their analogs or precursors under the laws of Ukraine}

Concerning objects that have been found, manufactured, adapted, or used as a means or instrument of committing a crime, it should be noted that according to Articles 331, 332 of the Civil Code of Ukraine (Law № 435-IV, 2004) they may have property rights because of the way they are used does not affect the legality of such grounds. If so, these items should be subject to confiscation of property, not asset forfeiture. If for the legislator the basis for the definition of a legal mode of these subjects is a way of their use, it should be specified in the law (Orlovskaya, 2016)

Proof the circumstances of the identity of the accused

Concerning the circumstances to be established during the prejudicial inquiry of a particular crime, we can distinguish general, which are characteristic of all crimes, and special, which are characteristic only of specific criminal acts.

To the general circumstances, the authors suggest to range as follows:

1) background information: surname, name, patronymic; date, month, year of birth; Place of birth; place of residence and registration; citizenship; nationality; education; type of occupation, specialty, position; attitude to military service; the presence of military or other special ranks, orders, awards, medals; 
2) qualities and properties that characterize the station in life of the accused, his orientation and functions in the system of social relations and life, namely those that reveal the individual properties of the accused, morality, behavior, data on relations in various spheres of public life, and factors of the social environment that affect the identity of the accused;

3) criminal-legal features and characteristics of the accused person (attitude to the committed crime, its consequences, behavior during the prejudicial inquiry in the criminal case (including the previous one, if any) and comparison of the behavior of accused during the criminal investigation);

4) psycho physiological features of the accused (Duda, 2010).

As for the special circumstances of a person who smuggles narcotic drugs, psychotropic substances, their analogs or precursors, he always exhibits deviant behavior and quite often can use such prohibited substances (Lichtenwald, 2003)

Proposals to expand the subject of proof in criminal proceedings

Shibiko V. notes that a kind of "novelty", or rather, it seems, the omission of the law is the lack of provisions in the current Criminal Procedure Code of Ukraine on the obligation of authorities conducting criminal proceedings to establish the causes and conditions that contributed to the commission of a criminal offense measures to eliminate them. He rightly proposes to add to the list of circumstances that are subject to proof in criminal proceedings (part 1 of Article 91 of the Criminal Procedure Code of Ukraine) paragraph "causes and conditions that contributed to the commission of a criminal offense" (Shibiko, 2013). Regarding the list of such reasons and conditions for the investigated criminal offense, we propose to consider them: the imperfection of customs policy, the inefficiency of customs tariffs, burden of the situation at customs, lack of proper selection of personnel and their material support, imperfection of technical means of checking when crossing the customs border.

\section{Conclusions}

Summarizing all the above-mentioned information, it should be noted that Ukraine has been and unfortunately remains an important partner for the international smuggling of drugs, psychotropic substances, their analogs or precursors. At the same time, it should be noted that in its desire to counteract this destructive phenomenon, many measures are taken and new methods of counteraction are introduced. An important aspect of counteraction, of course, is to ensure proper procedural support of criminal prosecution, persons who have committed a crime under Article 305 of the Criminal Code of Ukraine. That is why the subject of proof during the prejudicial inquiry of smuggling of narcotic drugs, psychotropic substances, their analogs or precursors should be expanded. Thus, we propose to include in it: the general circumstances to be proved in all criminal proceedings; circumstances specified in the disposition of Article 305 of the Criminal Code of Ukraine, and circumstances that are not part of the proof, but are important for the trial on the merits, for example, the identity of the accused and the circumstances of the causes and conditions of drugs, psychotropic substances, their analogs or precursors.

Funding: The research was carried out within the framework of project No.0120U100474 Development of Methods of Interaction between Law Enforcement Agencies of Ukraine on Counteraction to Money Laundering.

\section{Bibliographic references}

Bondarenko, O., Reznik, O., Yevgen, G., Andriichenko, N., \& Stohova, O. (2020). Participation of Ukraine in International Cooperation against Corruption. Amazonia Investiga, $\quad 9 \quad$ (29), $\quad$ 407-416. https://doi.org/10.34069/AI/2020.29.05.45

Buehnand, A., \& Farzanegan, M. R. (2012). Smuggling around the World: Evidence from a Structural Equation Model. Applied Economics, Vol 44(23), 3047-3964 Recovered from https://www.tandfonline.com/doi/full/10.1080/0 0036846.2011.570715?scroll=top\&needAccess $=$ true.

Convention against Illicit Traffic in Narcotic Drugs and Psychotropic Substances. (1988). Recovered

fromhttps://www.unodc.org/documents/commis sions/CND/Int_Drug_Control_Conventions/Ebo ok/The_International_Drug_Control_Conventio ns_E.pdf

Convention on Psychotropic Substances. (1971). Recovered from https://www.unodc.org/pdf/convention_1971_e n.pdf

Duda, A.V. (2010). Circumstances characterizing the identity of the accused as an element of the subject of evidence in a criminal case (doctoral thesis). National University of 
Internal Assets of Kyiv, Ukraine. Recovered from

https://dspace.nlu.edu.ua/bitstream/123456789/1 7847/1/Duda_2010.pdf

Express analysis of the state of crime related to drug smuggling in Ukraine in 2015. (2015). Kyiv: SBU.

Gatiyatullina, A., \& Samitov, E. (2019). Preliminary investigation in criminal proceedings. Colloquium-journal Philological Sciences, № 27, 219-222. Recovered from https://cyberleninka.ru/article/n/predvaritelnoerassledovanie-po-ugolovnym-delam/viewer Goncharenko, V., Nora, V., \& Shumila, M. (2012) Criminal Procedure Code of Ukraine: Scientific and practical commentary. Kyiv: Justinian. Unfortunately, there is no link on the Internet, the book is only printed.

Groot, L. (2013). Money laundering, drugs and prostitution as victimless crimes. Handbook Chapter, 11, 57-67. https://doi.org/10.4337/9780857934000.00013

Ishchenko, V. (2011). Theoretical model of proof in the criminal science of criminal procedure. Forum of Law, № 3, 309-321.

Komissarchuk, Yu. (2011). Definition and content of Criminal Procedure Evidence. Science and Law, № 56, 333-343.

Kostin, M. (2004). The concept of "proof" in the criminal process of Ukraine. Law of Ukraine, № $1,146-148$.

Krasiy, M. (2015) The event of a criminal offense in terms of the basis of criminal liability. Comparative and Analytical Law, № 5, 239-241. Law № 2341-III. Criminal Code of Ukraine. Information of the Verkhovna Rada of Ukraine, № 25-26, 2001. Recovered from https://zakon.rada.gov.ua/laws/show/2341-14 Law № 435-IV. Civil Code of Ukraine. Information of the Verkhovna Rada of Ukraine, $\mathrm{N}^{\circ}$ 40-44, 2004. Recovered from https://zakon.rada.gov.ua/laws/show/43515\#Text

Law № 4651-VI. Criminal Procedure Code of Ukraine. Information of the Verkhovna Rada of Ukraine, 10 9-10, № 11-12, 13, 2012. Recovered from https://zakon.rada.gov.ua/laws/show/465117

Law № 60/95-VR. On Narcotic Drugs, Psychotropic Substances and Precursors. Information of the Verkhovna Rada of Ukraine, № 10.1995 . Recovered from https://zakon.rada.gov.ua/laws/show/60/95$\% \mathrm{D} 0 \% \mathrm{~B} 2 \% \mathrm{D} 1 \% 80$

Lichtenwald, T. (2003). Drug Smuggling Behavior: A Developmental Smuggling Model (Part 1) By. Forensic Examiner, Nov/Dec 2003 Vol. 12, Part 1, 15-22.
MacKenzie, D. L., Mitchell, O., \& Wilson, D. B. (2011). The impact of drug treatment provided in correctional facilities. Issues in children's and families' lives. Handbook of evidence-based substance abuse treatment in criminal justice settings. Springer Science + Business Media. (p. 183-203)https://doi.org/10.1007/978-14419-9470-7_11

Malyuga, R. (2014) Proving the event of a criminal offense in criminal proceedings concerning the smuggling of narcotic drugs, psychotropic substances, their analogues or precursors or falsified drugs. Scientific Notes of Lviv University of Business and Law, № 5, 228231. Recovered from file:///D:/Downloads/Nzlubp_2014_12_53\%20( 3).pdf

Nastyuk, V., Mikhailov, O., Izbash, E., \& Kondratenko, V. (2020). Judicial control over investigative (search) actions that require prior permission. Amazonia Investiga, 9(28), 151-158. https://doi.org/10.34069/AI/2020.28.04.18

Nikiforchuk, D. (2006). Features of detection and documentation of smuggled drugs to Ukraine. Scientific Bulletin of KNUVS, № 1 Part 2, 39-45. Unfortunately, there is no link on the Internet, the paper is only printed

Orlovskaya, N. (2016). On the question of the subject of special confiscation. Latest Criminal Law Research, № 2, 44-47.

Pilnik, V. (2016). Drug smuggling: criminal characteristics and prevention. Scientific Bulletin of Uzhhorod National University, № 41, 126-129. Recovered from http://nbuv.gov.ua/UJRN/nvuzhpr_2016_41(2)_ 31.

Pirozhenko, O. (2015). Special confiscation: general aspects and evolution of domestic criminal law thought. Bulletin of the Criminological Association of Ukraine, № 3, 70-79.

Podorozhnii, Y., Obushenko, N., Harbuziuk, K., \& Platkovska, O. (2020). Legislative regulation of grounds for dismissal of an employee for committing a corruption or corruption-related offense. Amazonia Investiga, 9(26), 304-310. https://doi.org/10.34069/AI/2020.26.02.34

Ponomarenko, A., Havryliuk, L., Anheleniuk, A.M., \& Drozd, V. (2020). Inadmissibility of Evidence in Criminal Proceedings in Ukraine. Amazonia Investiga, 9(29), 147-155. https://doi.org/10.34069/AI/2020.29.05.17 Popelyushko, V.O. (2007). Circumstances mitigating criminal liability and punishment as a subject of protection. Lawyer, №3. 3-7. Recovered from 
https://eprints.oa.edu.ua/4586/1/Popeliushko_10 052016.pdf

Rybalka, O. (2011). The value of criminal procedural evidence. Science and Law, № 133, 15-21.

Shcheritsa, S. (2015). Evidence and proof in criminal proceedings. Bulletin of Zaporizhia National University, № 1(II), 202-208.Recovered from http://rep.btsau.edu.ua/bitstream/BNAU/652/3/ Dokazy_y_dokazuvan.pdf

Shevchuk, V.M (2003). Methods of investigation of smuggling: problems of theory and practice: a monograph. Kharkiv: Vulture.

Shibiko, V. (2013). Some novelties of the current CPC of Ukraine need further comprehension and improvement. Law of Ukraine, № 13, 104-111. Single Convention on Narcotic Drugs. (1961). Recovered from https://www.unodc.org/pdf/convention_1961_e n.pdf

Sofin, M. (2016). The type and amount of damage caused by a criminal offense, as a mandatory element of the subject of evidence by investigators in criminal proceedings. Scientific Bulletin of the National Academy of Internal Affairs. 99, 2(1), 253-262.

Soroka, S. O. (2015). Circumstances subject to proof in criminal proceedings during the investigation of drug smuggling. Lviv Polytechnic National University Institutional Repository, № 1, 287-291. Recovered from http://ena.lp.edu.ua:8080/bitstream/ntb/30162/1/ 046_287_291.pdf

Soroka, S., \& Rimarchuk, R. (2017). The legal nature of criminal procedural evidence. Bulletin of Lviv polytechnics national university. Series: legal sciences, № 3, 278-283.

Sui, B., Feng, G. \& Chang, C. (2018). The pioneer evidence of contagious corruption. Qual Quant, 52, 945-968. https://doi.org 10.1007/s11135-017-0497-4

Torbas, O. (2015). Circumstances to be implemented before drafting a motion on releasing the person from criminal liability.Visnyk Kriminalnogoh Sudochinstva, № 3, 88-94.

Tsimbalyuk, V. (2014). Legal nature of special confiscation. Journal of the National University "Ostroh Academy". Series "Law", № 2(10). Recovered from http://lj.oa.edu.ua/articles/2014/n2/14tvipsk.pdf Videnko, E. (2014). Civil lawsuit in the criminal proceedings of Ukraine as a "tool" to protect the rights of the victim. Comparative and Analytical Law, № 5, 368-370. 